\title{
Club Cell Secretory Protein (CCSP) is Reduced in Hospitalized Chronic Obstructive Pulmonary Disease (COPD) Exacerbations
}

This article was published in the following Dove Press journal: International Journal of Chronic Obstructive Pulmonary Disease

\author{
Arianne K Baldomero $\mathbb{D D}^{1,2}$ \\ Ken M Kunisaki (iD ${ }^{1,2}$ \\ John Connett ${ }^{3}$ \\ Aprile Pilon ${ }^{4}$ \\ Chris $\mathrm{H}$ Wendt ${ }^{1,2}$ \\ 'Pulmonary, Allergy, Critical Care, and \\ Sleep Medicine, Minneapolis VA Health \\ Care System, Minneapolis, MN, USA; \\ ${ }^{2}$ Pulmonary, Allergy, Critical Care, and \\ Sleep Medicine, University of Minnesota, \\ Minneapolis, MN, USA; ${ }^{3}$ Division of \\ Biostatistics, School of Public Health, \\ University of Minnesota, Minneapolis, \\ MN, USA; ${ }^{4}$ APCBio Innovations, Inc., \\ Rockville, MD, USA
}

\section{Introduction}

Acute exacerbations of chronic obstructive pulmonary disease (AECOPD) cause the majority of the morbidity, mortality, and health-care expenditure associated with COPD. The pathogenesis of AECOPD is complex, but oxidative stress has been implicated in AECOPD. Club cell secretory protein (CCSP), a molecule secreted by the non-ciliated bronchiolar Club cells, is thought to protect airways from oxidative stress and may be a therapeutic target in AECOPD. ${ }^{1}$ Previous studies have linked CCSP with COPD and lung function decline. ${ }^{2}$ However, no studies have investigated the association between CCSP levels and AECOPD.

Our objective was to determine if CCSP levels correlate with AECOPD by measuring plasma CCSP levels at the time of AECOPD hospitalization, and recovery compared to stable outpatients. We used data from two multicenter clinical trials of patients at increased risk of AECOPD to test the hypothesis that plasma CCSP levels are reduced in AECOPD compared to stable COPD.

\section{Methods}

We performed a case-control study (ratio 1:2, matched on age, sex, tobacco pack-years, and $\mathrm{FEV}_{1} \%$ predicted) where cases were hospitalized AECOPD patients from the Zileuton to Treat Adults with Chronic Obstructive Pulmonary Disease (LEUKO) study. All participants in the LEUKO study with plasma samples obtained at both hospital day 0 and 30 days post-hospitalization were included in the analyses. Matched stable controls were outpatients at high risk for AECOPD, but without exacerbations in the 4 weeks prior to study entry and blood draw, in the Macrolide Azithromycin to Prevent Rapid Worsening of Symptoms Associated with Chronic Obstructive Pulmonary Disease (MACRO) study. Plasma CCSP levels at hospital day 0 and day 30 posthospitalization for cases and at baseline for controls were quantified using commercially available ELISA kits (BioVendor, Candler, NC, USA). CCSP levels were transformed to a natural logarithmic scale to achieve normal distribution. To account for case-control matching, conditional logistic regression was used to determine the association between CCSP and case-control status. Serum creatinine was a covariate in adjusted models since CCSP levels are affected by kidney function and creatinine clearance predicts plasma CCSP levels. ${ }^{3} T$-tests were used to compare CCSP means between cases at hospital day 0 , day 30 post-hospitalization, and controls.
Correspondence: Arianne K Baldomero Pulmonary, Allergy, Critical Care, and Sleep Medicine, Minneapolis VA Health Care System, I Veterans Drive, Post Code: Pulmonary II IN, Minneapolis, MN, USA

Tel +1920-203-5517

Email baldo004@umn.edu
International Journal of Chronic Obstructive Pulmonary Disease 2020:I5 246|-2464

(C) 2020 Bald at This work is published and licensed by Dove Medical Press Limited. The full terms of this license are available at https://www.dovepress.com/ (c) ${ }_{\mathrm{BY}}$ NC terms.php and incorporate the Creative Commons Attribution - Non Commercial (unported, v3.0) License (http://creativecommons.org/licenses/by-nc/3.0/). By accessing the work you hereby accept the Terms. Non-commercial uses of the work are permitted without any further permission from Dove Medical Press Limited, provided the work is properly attributed. For permission for commercial use of this work, please see paragraphs 4.2 and 5 of our Terms (https://www.dovepress.com/terms.php) 


\section{Results}

We measured plasma CCSP levels in 30 cases and 60 controls. After exclusion of one case with extreme plasma CCSP levels (day 0: $125.56 \mathrm{ng} / \mathrm{mL}$; day 30: $136.73 \mathrm{ng} / \mathrm{mL}$ ) and the two matched controls for this case, we have 29 cases and 58 matched controls for analysis (Table 1). Median [interquartile range (IQR)] age of the cases was 61 [55-68] years, 45\% were females, 35\% were current smokers, median [IQR] smoking history of 40 [28-57] pack-years, mean $\mathrm{FEV}_{1} \%$ predicted was $28.8 \%$ and median [IQR] serum creatinine was 1.0 [0.8-1.1]. The controls had a median [IQR] age of 60 [56-68] years, 41\% were female, 26\% were current smokers, median [IQR] smoking history of 40 [30-50] packyears, mean $\mathrm{FEV}_{1} \%$ predicted was $34.6 \%$, and median [IQR] serum creatinine was 0.9 [0.8-1.1] mg/dL.

Hospitalized AECOPD (case) status was associated with reduced plasma CCSP levels compared to stable COPD (control) status, matched on age, sex, tobacco pack years, and $\mathrm{FEV}_{1} \%$ predicted. Each natural log unit increase in plasma CCSP was associated with a decreased odds for hospitalized AECOPD status in both unadjusted

Table I Baseline Characteristics

\begin{tabular}{|c|c|c|}
\hline & $\begin{array}{l}\text { Cases } \\
(n=29)\end{array}$ & $\begin{array}{l}\text { Controls } \\
(n=58)\end{array}$ \\
\hline Age, years (median [IQR]) & $61[55-68]$ & $60[56-68]$ \\
\hline Female, no. (\%) & $13(45 \%)$ & $24(41 \%)$ \\
\hline $\begin{array}{l}\text { Race or ethnic group, no. (\%) } \\
\text { White } \\
\text { African-American } \\
\text { Other }\end{array}$ & $\begin{array}{l}\text { I5 (52\%) } \\
\text { I3 (45\%) } \\
\text { I (3\%) }\end{array}$ & $\begin{array}{l}42(72 \%) \\
10(17 \%) \\
6(10 \%)\end{array}$ \\
\hline Current smoker, no. (\%) & $10(35 \%)$ & $15(26 \%)$ \\
\hline $\begin{array}{l}\text { Smoking history, pack-years (median } \\
{[\mathrm{IQR}] \text { ) }}\end{array}$ & 40 [28-57] & $40[30-50]$ \\
\hline $\begin{array}{l}\text { Spirometry (mean } \pm \text { SD) } \\
\text { FEV }, \text { L } \\
\mathrm{FEV}_{1} \% \text { predicted } \\
\text { FVC, L } \\
\mathrm{FEV}_{\mathrm{l}} / \mathrm{FVC} \text { ratio }\end{array}$ & $\begin{array}{l}0.8 \pm 0.4 \\
28.8 \pm 13.1 \\
2.0 \pm 0.6 \\
0.4 \pm 0.1\end{array}$ & $\begin{array}{l}1.0 \pm 0.5 \\
34.6 \pm 15.9 \\
2.5 \pm 0.9 \\
0.4 \pm 0.1\end{array}$ \\
\hline $\begin{array}{l}\text { Inhaled therapies, no (\%) } \\
\text { ICS } \\
\text { LABA } \\
\text { LAMA }\end{array}$ & $\begin{array}{l}24(83 \%) \\
22(76 \%) \\
17(59 \%)\end{array}$ & $\begin{array}{l}43(74 \%) \\
43(74 \%) \\
39(67 \%)\end{array}$ \\
\hline Serum creatinine, mg/dL (median [IQR]) & $1.0[0.8-1.1]$ & $0.9[0.8-1.1]$ \\
\hline
\end{tabular}

Notes: Definitions: Cases, hospitalized acute exacerbation in COPD; controls, stable COPD. Abbreviations: $\mathrm{FEV}_{1}$, forced expiratory volume in one second; FVC, forced vital capacity; ICS, inhaled corticosteroid; LABA, long-acting beta ${ }_{2}$-agonist; LAMA, longacting muscarinic antagonist; and SD, standard deviation. (odds ratio [OR] $0.347,95 \%$ confidence interval [CI]: 0.121 to $0.998, \mathrm{p}=0.0495$ ) and adjusted models that included serum creatinine as a covariate (adjusted OR $0.269,95 \%$ CI: 0.089 to $0.811, \mathrm{p}=0.0197$ ) (Table 2). The plasma CCSP (mean \pm standard deviation) at day 0 (1.53 $\pm 0.62 \mathrm{ng} / \mathrm{mL})$ vs controls $(1.79 \pm 0.51 \mathrm{ng} / \mathrm{mL})(\mathrm{p}=0.041)$ were significantly different, while day 0 vs day 30 (1.64 $\pm 0.60 \mathrm{ng} / \mathrm{mL})(\mathrm{p}=0.229)$ and day 30 vs controls were not significantly different $(\mathrm{p}=0.495)$.

\section{Discussion}

To our knowledge, this study is the first to evaluate plasma CCSP during an AECOPD. We found that lower plasma CCSP is associated with higher odds of hospitalized AECOPD status relative to matched stable COPD and that plasma CCSP levels 30 days following hospitalization are similar to stable controls.

CCSP is produced by the small airway club cell and is thought to protect airways from oxidative stress. ${ }^{1}$ Therefore, a reduction in CCSP levels during an AECOPD would result in increased susceptibility to oxidative stress, which could contribute to AECOPD severity. The increasing trend in plasma CCSP 30 days later, though not significantly different from hospitalization day 0 , is suggestive of airway epithelial cells recovery following an AECOPD.

We excluded one case with extreme plasma CCSP levels. This patient had a serum creatinine of $12.1 \mathrm{mg} / \mathrm{dL}$ indicating renal failure. Because plasma CCSP levels are affected by kidney function, ${ }^{3}$ it is likely that this extreme elevation in plasma CCSP levels is due to renal failure. Therefore, we accounted for renal function in our adjusted model.

CCSP has been evaluated in several COPD cohorts. Bernard et al found that bronchoalveolar lavage fluid CCSP levels were reduced in stable COPD compared to non-smoker controls. ${ }^{4}$ In the Evaluation of COPD Longitudinally to Identify Predictive Surrogate Endpoints (ECLIPSE) study, a 3-year multicentre prospective observational cohort of 2747 participants with COPD, Lomas et al found that median serum CCSP was lowest in COPD participants $(5.9 \mathrm{ng} / \mathrm{mL})$ compared to smoker $(6.3 \mathrm{ng} / \mathrm{mL})$ and non-smoker controls $(7.5 \mathrm{ng} / \mathrm{mL})$ without COPD. ${ }^{5}$ The median serum CCSP level among COPD participants in the ECLIPSE cohort is similar to our stable COPD control group $(5.50 \mathrm{ng} / \mathrm{mL})$, consistent with CCSP deficiency in patients with COPD. Low serum CCSP levels have been associated with accelerated lung function decline, ${ }^{2}$ which brings into question the possible role of CCSP augmentation therapy in COPD. 
Table 2 Conditional Logistic Regression Analyses for Predicting Hospitalized Acute Exacerbation in COPD (AECOPD) Case vs Matched Stable COPD Control Status

\begin{tabular}{|c|c|c|c|c|c|c|}
\hline \multirow[b]{2}{*}{$\begin{array}{c}\text { Plasma CCSP } \\
\text { (mean } \pm \text { SD) }\end{array}$} & \multirow{2}{*}{$\begin{array}{c}\text { Hospitalized } \\
\begin{array}{c}\text { AECOPD } \\
\text { Cases }(n=29)\end{array} \\
1.53 \pm 0.62\end{array}$} & \multirow{2}{*}{$\begin{array}{c}\begin{array}{c}\text { Stable } \\
\text { COPD }\end{array} \\
\text { Controls }(n=58) \\
1.79 \pm 0.5 \mid\end{array}$} & \multicolumn{2}{|c|}{$\begin{array}{l}\text { Unadjusted OR } \\
\quad(95 \% \mathrm{Cl})\end{array}$} & \multicolumn{2}{|c|}{$\begin{array}{c}\text { Adjusted OR } \\
(95 \% \mathrm{CI})\end{array}$} \\
\hline & & & $\begin{array}{c}0.347 \\
(0.121,0.998)\end{array}$ & $p=0.0495$ & $\begin{array}{c}0.269 \\
(0.089,0.8 \mathrm{II})\end{array}$ & $p=0.0197$ \\
\hline
\end{tabular}

Notes: Cases and controls were matched on age, sex, tobacco pack-years, and FEV $\%$ predicted. Plasma CCSP levels in ng/mL are in natural logarithmic scale. Adjusted model includes creatinine as a covariate.

Abbreviations: CCSP, club cell secretory protein; SD, standard deviation; $\mathrm{Cl}$, confidence interval.

Pre-clinical models of CCSP augmentation have demonstrated protective effects in both cellular and animal models. ${ }^{6}$ An ongoing clinical trial in premature infants with respiratory distress syndrome has shown that recombinant human CCSP can be safely delivered intratracheally, and a single dose reduces pulmonary inflammatory markers. ${ }^{7}$ Our findings support assessment of therapies targeting restoration of CCSP levels in COPD, specifically during an acute exacerbation or as a sustained, maintenance therapy in exacerbation-prone COPD patients.

Our study has limitations including a modest sample size and being observational, thus we are unable to establish causality. Whether reduction in CCSP levels is a risk factor for versus a consequence of AECOPD will need to be addressed in larger longitudinal and mechanistic studies. We did not have baseline plasma CCSP levels prior to hospitalization, which could have helped determine if levels at 30 days return to baseline, but because we were able to match on age, sex, tobacco pack-years, and $\mathrm{FEV}_{1} \%$ predicted, we theorize that our matched controls reflect baseline, pre-hospitalization plasma CCSP levels among exacerbation-prone COPD patients.

\section{Conclusion}

In conclusion, lower plasma CCSP is associated with hospitalized AECOPD. Clinical studies are needed to evaluate the efficacy of CCSP as a novel treatment for COPD, especially in AECOPD.

\section{Ethical Statement}

The MACRO and LEUKO studies were performed in accordance with the principles stated in the Declaration of Helsinki. Documented review and approval from each institution's Institutional Review Board (IRB) were obtained prior to starting the studies. The IRBs for the following sites reviewed and approved the MACRO study: Denver City-County Health/ Hospitals Department, University of Alabama at Birmingham,
Harbor-UCLA Medical Center, University of Minnesota, Temple University, University of California San Francisco, University of Michigan, Minneapolis VA Health Care System, Brigham and Women's Hospital, and University of Maryland. The following IRBs for the following sites reviewed and approved the LEUKO study: University of Alabama at Birmingham, Birmingham Alabama Veteran's Administration Medical Center, University of California San Francisco, Denver Health Medical Center, National Jewish Health, VA Eastern Colorado Health Care System, University of Maryland, Fallon Clinic Boston, Brigham and Women's Hospital, VA Boston Healthcare System, VA Ann Arbor Healthcare System, University of Michigan, Minneapolis VA Health Care System, HealthPartners Institute, Mayo Clinic, Temple University, and University of Pittsburgh. All study participants provided written informed consent.

\section{Acknowledgments}

This research was supported by the National Heart, Lung and Blood Institute (NHLBI) grant U10HL074424 (LEUKO and MACRO) for the COPD Clinical Research Network (CCRN). This material is also the result of work supported with resources of the Minneapolis VA Health Care System. We thank Helen Voelker and Sarah Lindberg, MPH from the Division of Biostatistics, University of Minnesota, Minneapolis, MN, for providing the data and biostatistical support.

\section{Disclosure}

KMK has received consulting fees from GlaxoSmithKline and Nuvaria, Inc. and reports contracted clinical research for Sanofi and AstraZeneca outside the submitted work and reports no conflicts of interest in this work. AP is the executive vice president and chief scientific officer at Therabon Therapeutics, Inc. AP is also the chief executive officer and cofounder at Trove Therapeutics, Inc., Empower Telehealth, Inc., and APCBio Innovations, Inc., and reports being a major 
owner of Trove Therapeutics, which is developing recombinant human $\mathrm{CC} 16$ as a therapeutic for respiratory disease, outside the submitted work. All of the other authors report that they have no affiliations with or involvement in any organization or entity with any financial or non-financial interest in the subject matter or materials discussed in this manuscript, and have no conflicts of interest in this work. The views expressed in this article are those of the authors and do not reflect the views of the United States Government, the Department of Veterans Affairs, the funders, the sponsors, or any of the author's affiliated academic institutions.

\section{References}

1. Boers JE, Ambergen AW, Thunnissen FB. Number and proliferation of clara cells in normal human airway epithelium. Am J Respir Crit Care Med. 1999;159:1585-1591. doi:10.1164/ajrccm.159.5.9806044

2. Guerra S, Halonen M, Vasquez MM, et al. Relation between circulating $\mathrm{CC} 16$ concentrations, lung function, and development of chronic obstructive pulmonary disease across the lifespan: a prospective study. Lancet Respir Med. 2015;3:613-620. doi:10.1016/S2213-2600(15) 00196-4
3. Hermans C, Dong P, Robin M, et al. Determinants of serum levels of surfactant proteins A and B and clara cell protein CC16. Biomarkers. 2003;8(6):461-471. doi:10.1080/13547500310001647021

4. Bernard A, Marchandise FX, Depelchin S, Lauwerys R, Sibille Y. Clara cell protein in serum and bronchoalveolar lavage. Eur Respir $J$. 1992;5:1231-1238.

5. Lomas DA, Silverman EK, Edwards LD, Miller BE, Coxson HO, Tal-Singer R. Investigators EoCLtIPSEE. Evaluation of serum CC-16 as a biomarker for COPD in the ECLIPSE cohort. Thorax. 2008;63 (12):1058-1063. doi:10.1136/thx.2008.102574

6. Laucho-Contreras ME, Polverino F, Tesfaigzi Y, Pilon A, Celli BR, Owen CA. Club Cell Protein 16 (CC16) augmentation: a potential disease-modifying approach for Chronic Obstructive Pulmonary Disease (COPD). Expert Opin Ther Targets. 2016;20(7):869-883. doi: $10.1517 / 14728222.2016 .1139084$

7. Levine CR, Gewolb IH, Allen K, et al. The safety, pharmacokinetics, and anti-inflammatory effects of intratracheal recombinant human Clara cell protein in premature infants with respiratory distress syndrome. Pediatr Res. 2005;58(1):15-21. doi:10.1203/01. PDR.0000156371.89952.35

\section{Publish your work in this journal}

The International Journal of COPD is an international, peer-reviewed journal of therapeutics and pharmacology focusing on concise rapid reporting of clinical studies and reviews in COPD. Special focus is given to the pathophysiological processes underlying the disease, intervention programs, patient focused education, and self management protocols. This journal is indexed on PubMed Central, MedLine and CAS. The manuscript management system is completely online and includes a very quick and fair peer-review system, which is all easy to use. Visit http://www.dovepress.com/testimonials.php to read real quotes from published authors. 